\section{The Spectre of Internationalization in Croatian Sociology}

\section{Bauk internacionalizacije u hrvatskoj sociologiji}

\begin{abstract}
Valerio BAĆAK
Department of Sociology, University of Pennsylvania, Philadelphia, USA

Odsjek za sociologiju Filozofskog fakulteta Sveučilišta u Zagrebu / Department of Sociology, Faculty of Humanities and Social Sciences, University of Zagreb, Croatia vbacak@sas.upenn.edu
\end{abstract}

In the last issue of the Revija za sociologiju, Mirko Petrić (2011) drew attention to the limitations associated with the recent bibliometric analysis of the international productivity of Croatian sociologists (Štulhofer, Baćak, and Šuljok, 2010). ${ }^{1}$ His thorough, although tendentious, contextualization is important to view the bibliometric data from a more comprehensive perspective. The problems, however, arise with the implications drawn from that critical contextualization. A substantial part of his comment consists of a speculation about the possible negative consequences of the effort to internationalize. Even though he notes in a few instances that he agrees with the finding that international productivity of senior Croatian sociologists is insufficient, the expressed fears of academic imperialism

\footnotetext{
${ }^{1}$ I would like to thank Jasmina Božić, Teo Matković, Chris Reece, Sarah Spell, Damir Šoh, Aleksandar Štulhofer, Adrijana Šuljok, and Tanja Vučković Juroš for suggestions that helped improve the manuscript. I especially thank Jadranka Čačić-Kumpes for very critical, but useful comments.
}

U prošlom broju Revije za sociologiju, Mirko Petrić (2011) upućuje na ograničenja nedavne bibliometrijske analize međunarodne produktivnosti hrvatskih sociologa (Štulhofer, Baćak i Šuljok, 2010). ${ }^{1}$ Njegova podrobna, iako na trenutke tendenciozna, kontekstualizacija važna je kako bismo bibliometrijske podatke sagledali iz potpunije perspektive. No, problematične su implikacije do kojih Petrić dolazi na osnovi te kritičke kontekstualizacije. Znatan dio njegova komentara bavi se spekulacijama o mogućim negativnim posljedicama zalaganja za internacionalizaciju. Iako u više navrata napominje kako se slaže s nalazom da je međunarodna produktivnost etabliranih hrvatskih sociologa nedovoljna, izražena bojazan od akademskog imperijalizma i kompromitiranja

\footnotetext{
${ }^{1}$ Na komentarima koji su pomogli unaprijediti ovaj osvrt zahvaljujem Jasmini Božić, Teu Matkoviću, Chrisu Reeceu, Sarah Spell, Damiru Šohu, Aleksandru Štulhoferu, Adrijani Šuljok i Tanji Vučković Juroš. Osobito zahvaljujem Jadranki Čačić-Kumpes na vrlo kritičkim, ali korisnim komentarima.
} 
and of compromising individual research missions suggest that the agreement is only partial. Otherwise, why would he stress, without qualification (or providing a context) that we are actually a third sociological force in Europe? It is important to point out that in Christian Fleck's (2010) bibliometric analysis that he refers to, Croatian journals are also taken into account, which were not included in our analysis because publishing in local journals, even if they are referred in relevant databases, tells little about global scientific presence. ${ }^{2}$ Visibility and an intellectual impact of Croatian sociology can principally be achieved by increasing the international publication output. And there is no doubt that such an effort can and has to go along with increasing the quality of local publications to an international level, a road that the Revija za sociologiju is already taking.

Petric warns of the challenges that Croatian sociology might presumably face in its effort at internationalization. Young

${ }^{2}$ Petrić also devotes space to commenting on the credibility of the impact factor as an indicator of quality of social science journals. That is an odd (and redundant) discussion in the context of our bibliometric analysis because we did not claim at any point that the impact factor is an authoritative indicator of quality or importance of a journal. In addition, we have included in the analysis many journals that did not even have an impact factor. It is important to add a reminder, therefore, that our intention was not to argue that the impact factor tells anything about the importance of individual journals. We wanted to examine whether senior Croatian sociologists are present in international peer-reviewed journals that are available to potential readership worldwide through the relevant and relatively selective bibliographic databases. vlastitih istraživačkih misija sugeriraju da je slaganje tek djelomično. Zašto bi inače bez kvalificiranja (ili kontekstualizacije) bilo izdvojeno kako smo zapravo treća sociološka sila u Europi? U bibliometrijskoj analizi Christiana Flecka (2010), na koju se pritom referira, treba napomenuti, uzeti su u obzir i hrvatski časopisi, koje smo izostavili iz naše analize jer objavljivanje u lokalnim časopisima, makar referiranima u relevantnim bazama, govori malo o globalnoj znanstvenoj prisutnosti. ${ }^{2}$ Vidljivost i intelektualni utjecaj hrvatske sociologije mogu se ponajprije podići većom prisutnošću u međunarodnim publikacijama. Nedvojbeno je da pritom internacionalizacija može i mora ići istodobno $\mathrm{s}$ podizanjem kvalitete domaćeg izdavaštva na međunarodnu razinu, što je smjer kojim je Revija za sociologiju već krenula.

Petrić upozorava na izazove pred kojima se hrvatska sociologija navodno može naći u nastojanju na vlastitoj

${ }^{2}$ Petrić prostor posvećuje i komentiranju vjerodostojnosti čimbenika utjecaja kao indikatora kvalitete društvenoznanstvenih časopisa. U sklopu osvrta na našu bibliometrijsku analizu, riječ je o neobičnoj (i suvišnoj) raspravi jer niti u jednom trenutku nismo tvrdili da je čimbenik utjecaja mjerodavan indikator kvalitete ili važnosti časopisa. Uz to, u našu smo analizu uključili i mnoge časopise koji čimbenik utjecaja nisu niti imali. Bitno je stoga podsjetiti da nismo namjeravali tvrditi kako čimbenik utjecaja bilo što govori o važnosti pojedinih časopisa, nego smo htjeli istražiti jesu li etablirani hrvatski sociolozi prisutni u recenziranim međunarodnim časopisima koji su, putem relevantnih i razmjerno selektivnih referentnih baza, dostupni zainteresiranim čitateljima diljem svijeta. 
and ambitious Croatian sociologists, it is stressed, can be tempted to "act in tune with the priorities set before them by others, in order to be published and to be quoted" and thereby betray "the demands of one's own academic specialization" or the "burning needs of the society in which one is active as a researcher" (Petrić, 2011: 111). When publishing abroad they have to be careful, the author cautions further, not to compromise "one's research mission" and "the responsibility of the discipline to the local community, in the conditions of an ever more globalized research system whose success criteria are frequently remote from local needs" (Petrić, 2011: 109). Based on these statements, one can conclude that what is at stake here is an unfounded fear of publishing in international journals. When expressing such concerns, it is wrong and potentially harmful to reduce the importance of the finding that senior Croatian sociologists do not publish enough abroad by suggesting that internationalization can lead to a betrayal of the responsibility that national sociology has towards the problems of its own society. In sociology, like in the other social sciences, theoretically and methodologically sound works should have an intellectual significance for communities broader than the ones in which they were produced. That is why there is no reason to think that publishing outside of the country and local social responsibility could be in conflict. As a kind of rationale for low international productivity, the conclusion about sociological responsibility towards the local community only helps us to feel better on a palliative level when, in fact, we should be very concerned.

With the emphasis placed on the local social problems, Petrićs comment partly reflects what has been described internacionalizaciji. Mladi i ambiciozni hrvatski sociolozi, ističe, mogu doći u iskušenje da »u skladu s prioritetima mogućnosti objave i postizanja citatnog odjeka« iznevjere »zahtjeve vlastite akademske specijalizacije ili goruće potrebe društva u kojem se kao znanstvenik/ca djeluje« (Petrić, 2011: 111). Prilikom objavljivanja u inozemstvu oni moraju paziti, dalje se upozorava, da ne iznevjere »vlastite istraživačke misije« i »odgovornost discipline prema lokalnoj zajednici, u uvjetima sve globaliziranijega znanstvenog pogona čiji su kriteriji uspješnosti često daleko od lokalnih potreba« (Petrić, 2011: 109). Na osnovi tih se tvrdnji može zaključiti da je riječ o neutemeljenoj bojazni prema objavljivanju u međunarodnim časopisima. Pritom je pogrešno i potencijalno štetno relativizirati nalaze da etablirani hrvatski sociolozi nedovoljno objavljuju u inozemstvu sugeriranjem kako internacionalizacija može dovesti do iznevjeravanja obveze koju nacionalna sociologija ima prema problemima vlastitog društva. U sociologiji, kao i u drugim društvenim znanostima, teorijski i metodološki kvalitetni radovi imaju intelektualni značaj za zajednice šire od onih u kojima su proizvedene. Zato ne postoji razlog zbog kojeg bi objavljivanje izvan zemlje i lokalna društvena odgovornost mogli biti u sukobu. Zaključak o odgovornosti prema lokalnoj zajednici, kao svojevrsna racionalizacija niske međunarodne produktivnosti, samo nam palijativno pomaže da se osjećamo bolje kad bismo, zapravo, trebali biti vrlo zabrinuti.

S naglaskom koji stavlja na lokalne društvene probleme, Petrićev komentar djelomično izražava ono što je, 
in recent sociological debates, probably in an overly vulgar manner, as methodological nationalism (cf. Mesić, 2007; Beck and Sznaider, 2006): "the territorialization of social science imaginary and the reduction of the analytical focus to the boundaries of the nation-state" (Wimmer and Glick Schiller, 2002: 307). Why would he otherwise contend that individual research missions and the needs of the local community could be severely compromised by deciding to publish abroad? On the contrary, presence in the leading ${ }^{3}$ international journals can only, among other benefits, provide us with more confidence in the findings and conclusions of Croatian sociological research. Related to that, there is no basis for the dilemma between the local and the global put forth in the form of an alternative to "publish globally and perish locally" or "publish locally and perish globally" (Petrić, 2011: 111). There is also no foundation for an unaccounted claim about a number of "mechanisms of exclusion of certain topics and approaches from international journal production" (Petrić, 2011: 111). ${ }^{4}$ An unintended con-

\footnotetext{
${ }^{3}$ Petrić (2011: 101) argues that in sociology "there is no clear hierarchy of journals in that discipline, in contrast with some other branches and fields of science". Such a claim, actually, does not correspond to the disciplinary circumstances, especially at the international level. In addition to there being a hierarchy of generalist journals, although it cannot be necessarily ascertained from the bibliometric impact factor, a similar hierarchy exists within individual specialty areas. If we had focused on assessing the international presence in the leading specialty or generalist journals, our findings maybe could have been even more negative.

${ }^{4}$ Equally problematic is the implication that peer-reviewed papers published in journals
}

vjerojatno suviše vulgarno, u nedavnim sociološkim polemikama opisano kao metodološki nacionalizam (usp. Mesić, 2007; Beck i Sznaider, 2006): »teritorijalizacija imaginarija društvene znanosti i sužavanje njezinog analitičkog fokusa $u$ granice nacionalne države« (Wimmer i Glick Schiller, 2002: 307). Zašto bi se inače navelo da bi individualne istraživačke misije i lokalne potrebe mogle biti drastično iznevjerene odlukom o objavljivanju u inozemstvu? Upravo suprotno, pojavljivanje u vodećim $^{3}$ međunarodnim časopisima može nam, između ostalog, samo dati više povjerenja u nalaze i zaključke hrvatskih socioloških istraživanja. Vezano uz to, nema utemeljenja za dvojbu između lokalnog i globalnog koja se predstavlja u vidu suprotstavljanja alternative "globalnog objavljivanja i lokalnog nestajanja« ili »lokalnog objavljivanja i globalnog nestajanja« (Petrić, 2011: 111). Jednako tako nema osnove niti za neobrazloženu tezu o nizu »mehanizama isključivanja pojedinih tema i pristupa iz međunarodne časopisne produkcije« (Petrić, 2011: 111). ${ }^{4}$ Nenamjeravana

\footnotetext{
${ }^{3}$ Petrić (2011: 101) tvrdi da u sociologiji »nema jasne hijerarhije važnosti časopisa, kao što je to slučaj u nekim drugim poljima i područjima«. Takva tvrdnja, zapravo, ne odgovara disciplinarnim okolnostima, pogotovo na međunarodnoj razini. Osim što postoji hijerarhija općih časopisa, iako se ona ne može nužno iščitati iz bibliometrijskog čimbenika utjecaja, slična hijerarhija postoji i unutar pojedinih područja. Da smo se fokusirali na međunarodnu prisutnost u vodećim specijaliziranim ili općim časopisima, nalazi bi možda bili još negativniji.

${ }^{4}$ Jednako je problematična i implikacija da recenzirani radovi u domaćim časopisima odgovaraju na potrebe lokalne zajednice.
} 
sequence of such arbitrary statements can be to discourage sociologists at the start of their careers, who want to present their work outside of the country and, in doing so, build professional bridges with colleagues from abroad.

With the growing global economic, political, and cultural convergence, societies are becoming more interdependent, similar, and interested in each other. Even if the parochial notion of national sociology was meaningful at one time, it is now time to leave it behind completely, not only partially. One of the conclusions of a recent evaluation of the University of Zagreb by foreign experts in co-operation with local scientists was that research productivity, especially in leading international journals, is not in line with the university's status and size (Kralj et al., 2011). Another conclusion from the same evaluation, although less directly related to the topic, was that international staff and student mobility at the largest and most prestigious Croatian university is very low. According to those findings, when entering the European Union, we will soon compete with European colleagues for the same resources with very limited individual and institutional research capacities, and little experience in academic co-operation within and outside of Europe. We therefore have

at home address the needs of the local community. We simply do not have the data that would allow us to claim that such a relationship between Croatian sociology and Croatian society indeed exists. We also do not have the basis on which to assume that Croatian sociology in the future will become locally responsible, through the local peer-reviewed journals, in a way that sociologists choose topics that, by some consensus, represent the key social problems in the country. posljedica takvih proizvoljnih tvrdnji može biti da se obeshrabre sociolozi na početku karijere koji svoj rad žele predstaviti izvan zemlje i tako izgraditi profesionalne mostove prema kolegama iz inozemstva.

$\mathrm{S}$ rastućom globalnom ekonomskom, političkom i kulturnom konvergencijom društva postaju međusobno ovisnija, sličnija i zainteresiranija jedna za druge. Ako je provincijalni koncept nacionalne sociologije ikad imao svrhu, sad ga treba potpuno, a ne tek djelomično, odbaciti. Jedan od zaključaka nedavne evaluacije Sveučilišta u Zagrebu od stranih stručnjaka u suradnji s lokalnim znanstvenicima bio je da istraživačka produktivnost, osobito u vodećim svjetskim časopisima, nije u skla$\mathrm{du}$ s veličinom i statusom sveučilišta (Kralj i dr., 2011). Drugi zaključak iste evaluacije, iako neizravno vezan za ovu temu, jest da na najvećem i najprestižnijem hrvatskom sveučilištu postoji vrlo niska razina međunarodne mobilnosti istraživača i studenata. Sudeći po tim nalazima, s europskim ćemo se kolegama ulaskom u Europsku uniju uskoro nadmetati za iste resurse, a za to ćemo imati vrlo ograničene individualne $i$ institucionalne istraživačke kapacitete kao i skromno iskustvo europske i izvaneuropske akademske suradnje. Stoga se

Jednostavno nemamo podatke koji bi nam omogućili da tvrdimo kako takva veza između hrvatske sociologije i hrvatskog društva doista postoji. Također nemamo na osnovi čega pretpostaviti kako će hrvatska sociologija u budućnosti postati lokalno odgovorna, putem lokalnih recenziranih časopisa, na način da sociologinje i sociolozi odabiru teme koje, prema nekom konsenzusu, predstavljaju ključne društvene probleme u zemlji. 
to engage internationally soon and seriously in the form of, primarily, placing Croatian studies into leading international publications.

I thank Mirko Petrić for the effort he invested in illuminating our bibliometric findings and providing them with a context. The implications and claims that he delves into, however, are not justified. There is no need to fear that we will harm Croatian sociology or Croatian society by insisting on internationalization. It is important to add here that publishing outside of the country is not and must not be the only criterion of internationalization. It is, however, a key and indispensable one if we are interested in visibility and intellectual impact. In doing so we are placing Croatian sociology on the global scientific map, stimulating international co-operation, improving the quality of our research, and contributing to the development of sociology beyond national borders. After we have recognized, along with all the limitations of the bibliometric analysis, that our international productivity is scarce, the next step should be - and that was the intention of my comment - to examine the potential reasons behind parochialism. One of them is undoubtedly the spectre of scientific internationalization rooted in unfounded fears of academic imperialism.

\section{LITERATURA / REFERENCES}

Beck, Ulrich \& Sznaider, Natan (2006). »Unpacking cosmopolitanism for the social sciences: A research agenda«, The British Journal of Sociology, 57 (1): 1-23. doi:10.1111/ j.1468-4446.2006.00091.x

Fleck, Christian (2010). »Diversity or Fragmentation in Europe's Sociology: Lessons to be Learned?«, moramo što prije i što ozbiljnije poduhvatiti internacionalizacije, ponajprije kao plasiranja hrvatskih istraživanja $\mathrm{u}$ vodeće međunarodne publikacije.

Mirku Petriću zahvaljujem na trudu koji je uložio da rasvijetli naše bibliometrijske nalaze i pruži im kontekst. Implikacije i navodi u koje se upušta, međutim, nisu opravdani. Nema potrebe za bojazan da inzistiranjem na internacionalizaciji možemo naštetiti hrvatskoj sociologiji ili hrvatskom društvu. Bitno je pritom dodati da objavljivanje izvan zemlje nije i ne smije biti jedini kriterij internacionalizacije, ali je ključan i nezaobilazan, pogotovo ako nas zanimaju vidljivost i intelektualni utjecaj. Tako hrvatsku sociologiju stavljamo na globalnu znanstvenu mapu, potičemo međunarodnu suradnju, unapređujemo kvalitetu naših istraživanja i pridonosimo razvoju sociologije onkraj nacionalnih granica. Nakon što smo ustvrdili, uza sva ograničenja bibliometrijske analize, da nismo dovoljno međunarodno produktivni, sljedeći bi korak trebao biti - što je bila i namjera ovog komentara - osvrnuti se na potencijalne razloge za provincijalnost. Jedan je od njih nesumnjivo i bauk znanstvene internacionalizacije ukorijenjen u neutemeljenim strahovima od akademskog imperijalizma.

in: Michael Burawoy, Mau-kuei Chang \& Michelle Fei-yu Hsieh (eds). Facing an Unequal World: Challenges for a Global Sociology (Volume 3: Europe and Concluding Reflections). Taipei: Institute of Sociology, Academia Sinica, Council of National Associations of the International Sociological Association, 3-22. 
Kralj, Alojz, Lanarès, Jacques, Vardar, Öktem, Stråhlman, Christian \& Purser, Lewis (2011). University of Zagreb: Evaluation Report. EUAInstitutional Evaluation Programme.

Mesić, Milan (2007). »Metodološki kozmopolitizam versus metodološki nacionalizam«, Revija za sociologiju, 38 (1-2): 71-83.

Petrić, Mirko (2011). »Bibliometrija cum grano / Bibliometrics cum grano«, Revija za sociologiju, 41 (1): 99-114.
Štulhofer, Aleksandar, Baćak, Valerio \& Šuljok, Adrijana (2010). »Provincijalni karakter hrvatske sociologije? / A Parochial Status of Croatian Sociology?«, Revija za sociologiju, 40 (1): 103-108.

Wimmer, Andreas i Glick Schiller, Nina (2002). »Methodological nationalism and beyond: Nation-state building, migration and the social sciences«, Global Networks, 2 (4): 301-334. 